\title{
Cystathionase: Immunochemical Evidence for Absence from Human Fetal Liver
}

\author{
Theresa A. Pascal ${ }^{[19]}$, Bruge M. Gillam, and Gerald E. Gaull \\ Department of Pediatric Research, New York State Institute for Research in Mental Retardation, Staten Island, and Department of \\ Pediatrics, Mount Sinai School of Medicine of the City University of New York, New York, New York, USA
}

\section{Extract.}

Purified human liver cystathionase was obtained by ammonium sulfate fractionation (45-65\% saturation), starch block electrophoresis, and disc gel electrophoresis. Antibodies to the human enzyme were induced in the rabbit using cystathionase in polyacrylamide disc gel as antigen.

A pooled homogenate of liver from 14 human fetuses $(5.7$ to $20 \mathrm{~cm}$ crown-rump length), obtained at therapeutic abortion, was compared by agar double diffusion with an homogenate from normal human adult liver. A specific enzymatic stain, using cystathionine as substrate, was used to detect cystathionase activity in the immune precipitate. The extract of fetal liver did not form an enzymatically inactive immune precipitin band uniting with the catalytically active band formed between the adult liver and the antiserum. This absence was confirmed by immunotitration studies using a mixture of adult and fetal liver extracts in which the amount of fetal liver extract was equivalent to three times the total protein in the adult liver extract. The addition of fetal liver did not appreciably increase the amount of cystathionase activity remaining in the supernatant after combination with a given quantity of antibody and centrifugation to remove the enzyme-antibody complex.

\section{Speculation}

Human fetal liver does not contain an enzymatically inactive precursor protein immunologically related to adult human liver cystathionase, giving evidence that the human fetus is not competent to synthesize more than trace amounts of the intact enzyme.

\section{Introduction}

During late fetal and early postnatal life, the synthesis of many new enzymes is induced, and changes take place in the activity of numerous enzymes already present. In particular, several enzymes catabolizing amino acids are known to develop after birth: tyrosine aminotransferase (EC. 2.6.1.5) [5, 6], tryptophan oxygenase (EC. 1.12.1.12) [8], histidase (EC. 4.2.1.3) [1], and serine dehydratase (EG. 4.2.1.13) [5, 7].
Activity of cystathionase (L-homoserine hydro-lyase [deaminating], EC. 4.2.1.15) is not measurable in the livers of human fetuses and premature infants, although other enzymes of the sulfur pathway, namely cystathionine synthase (L-serine hydro-lyase [adding homocysteine], EC. 4.2.1.21) and methionine-activating enzyme (ATP: L-methionine $S$-adenosyltransferase, EC. 2.5.1.6), are present [11]. Since cystathionase does not appear until after birth, it was suggested that cyst(e)ine, a product of cystathionase, may be an essen- 
tial amino acid for the human fetus and premature infant [11]. It was thus of clinical as well as theoretical interest to determine whether the human fetus is competent to synthesize cystathionase. Such data might be relevant to attempts at facilitating the metabolic adjustment to premature extrauterine existence.

Immunochemical studies were initiated to determine whether the virtual absence of cystathionase activity is due to the presence in the fetus of a precursor enzyme protein, as yet inactive, but immunochemically related to the adult enzyme, or whether the fetus is not equipped at this stage to synthesize the intact enzyme protein.

\section{Materials and Methods}

Human liver cystathionase was purified by a procedure which included homogenization, precipitation by ammonium sulfate between 45 and $65 \%$ saturation, and starch block and disc gel electrophoresis [12]. Enzymatic activity was measured as previously described [4,
12]; 1 unit (U) of enzyme is that amount catalyzing the formation of $1 \mu$ mole of product per min.

Antiserum to human liver cystathionase was obtained by a method similar to that of Weintraub and Raymond [13], using as antigen cystathionase in polyacrylamide disc gel. The enzyme was located by slicing the gel into $2-\mathrm{mm}$ thick segments. One-third of each segment was assayed for cystathionase activity by placing in a test tube with $0.1 \mathrm{ml} 0.03 \mathrm{~m}$ potassium phosphate buffer, $\mathrm{pH} 6.9$, containing $1 \mathrm{~mm}$ disodium ethylenediamine, and $0.2 \mathrm{ml} 0.2 \mathrm{~m}$ Tris-HCl buffer, $\mathrm{pH} 7.5$, containing $2.5 \mathrm{~mm}$ dithiothreitol. Bovine serum albumin, $0.1 \mathrm{mg}$ per tube, was added to aid enzyme stability. After standing at $4^{\circ}$ for $2 \mathrm{hr}$, the assay was initiated by addition of the coenzyme and substrate. The remaining portions of those segments found to contain cystathionase were pooled, placed into $2 \mathrm{ml} 0.15 \mathrm{M}$ $\mathrm{NaCl}$, containing $0.01 \mathrm{~m}$ sodium phosphate buffer, $\mathrm{pH}$ 7.5, and pulverized with a tissue homogenizer [15]. The material from a number of runs, containing approximately $0.3 \mathrm{mg}$ cystathionase, was added to $2 \mathrm{ml}$ of

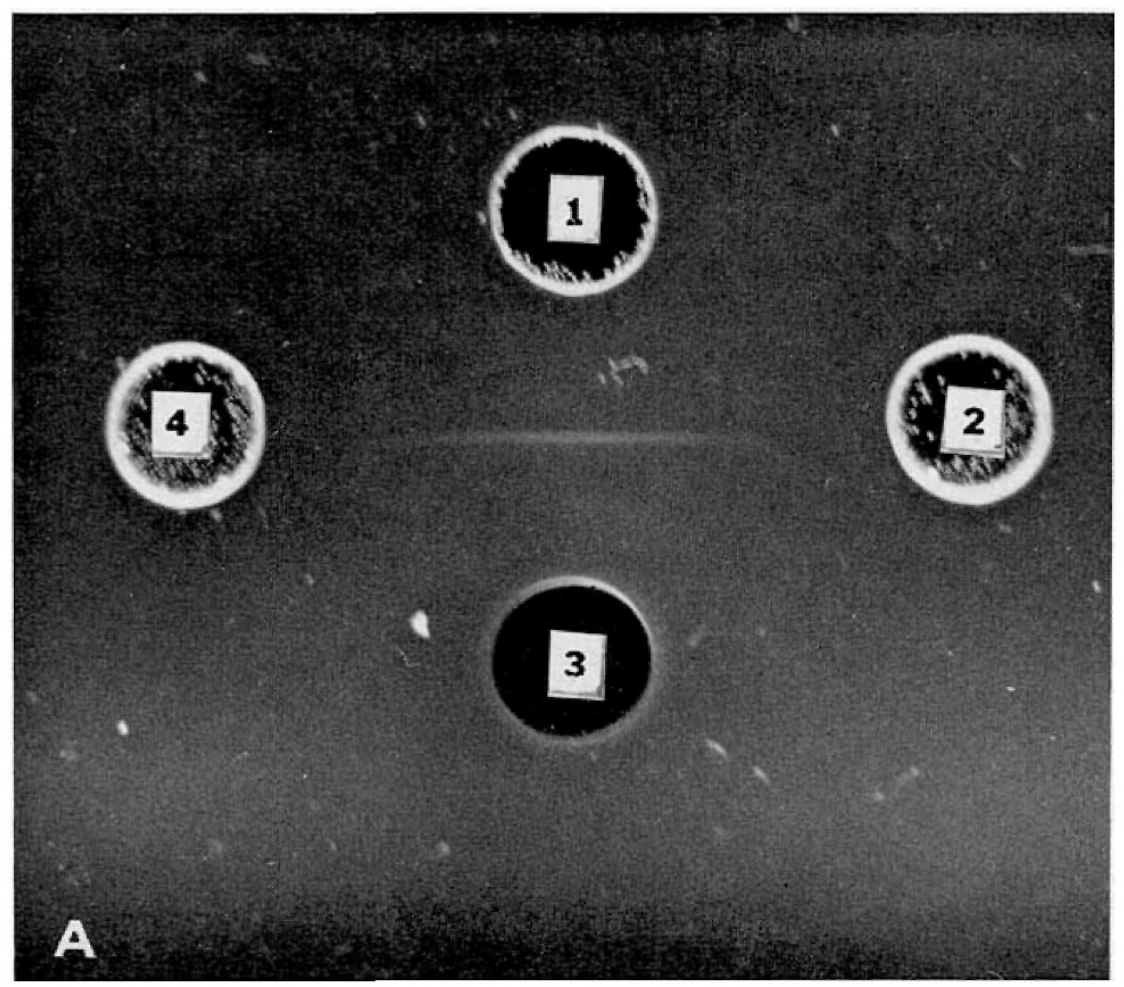

Fig. 1. Agar diffusion analysis of human adult and fetal liver extracts. A: Well 1 contains adult liver extract $(40 \mathrm{mg} / \mathrm{ml}$ protein). Wells 2 and 4 contain fetal liver extract $(40 \mathrm{mg} / \mathrm{ml}$ protein). Well 3 contains antiserum to human adult liver extract. $B$ : The same as $A$, but after specific enzyme stain for cystathionase activity. $C$ : Wells 1,3 , and 5 contain antiserum to adult human cystathionase absorbed with lyophilized fetal liver extract; wells 2, 4, and 6 contain antiserum absorbed with lyophilized crude adult liver extract. The center well contains adult liver extract. 
4

Fiz. IB.

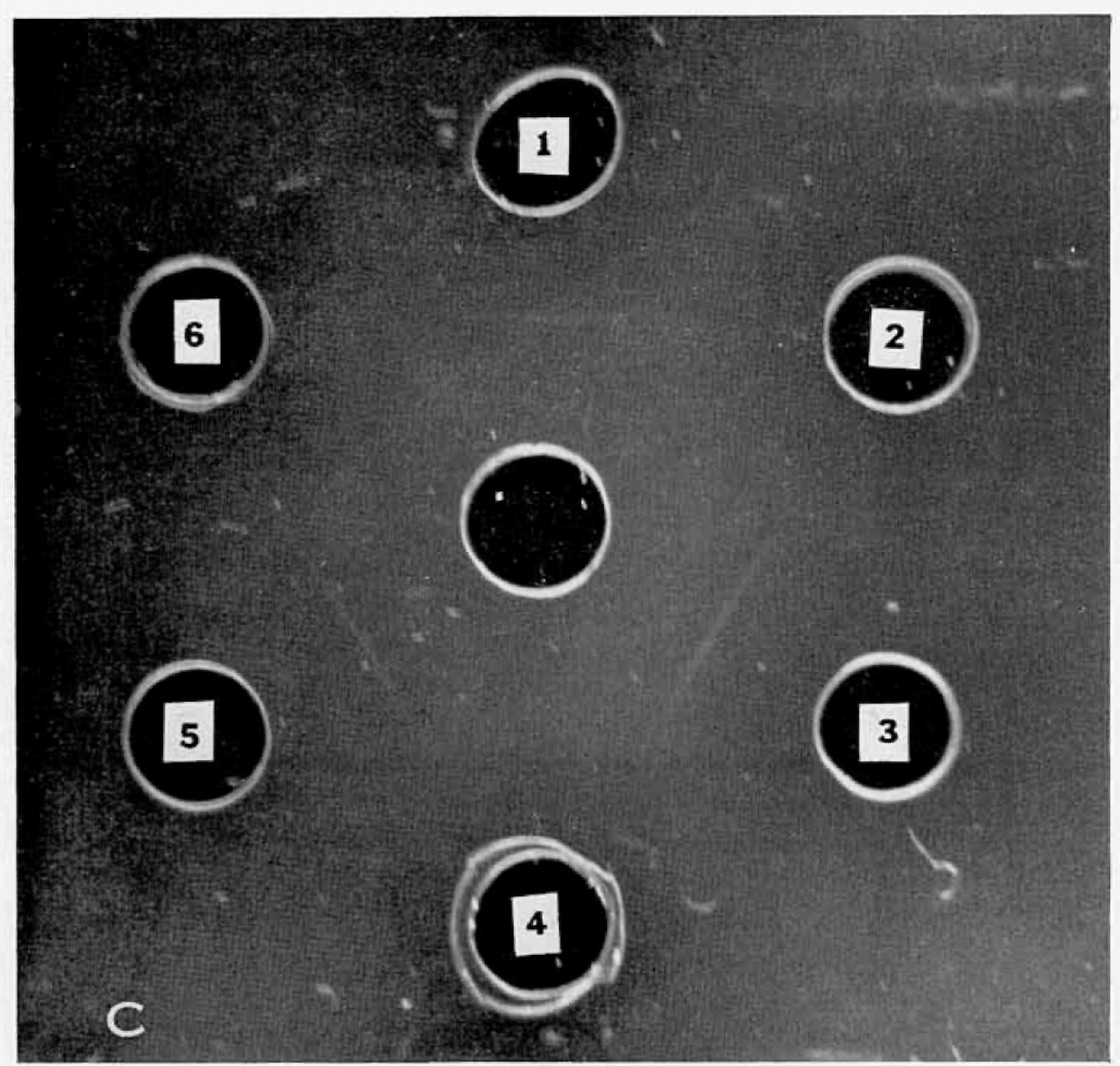

Fig. IC. 
complete Freund's adjuvant and injected intramuscularly into a male New Zealand albino rabbit on two separate occasions 4.5 weeks apart. Ten days after the second injection, precipitating antibodies to human cystathionase were detected by agar double diffusion analysis. The animal was killed 2.5 weeks after the second injection, and $40 \mathrm{ml}$ serum were collected.

Livers from 14 human fetuses $(5.7-20 \mathrm{~cm}$ crownrump length), obtained at therapeutic abortion, were pooled, homogenized in ice-cold $0.03 \mathrm{M}$ potassium phosphate buffer, pH 6.9 (containing $1 \mathrm{~mm}$ dithiothreitol, $1 \mathrm{~mm}$ disodium ethylenediaminetetracetate, and $50 \mu \mathrm{M}$ pyridoxal-5'-phosphate), and centrifuged at $43,500 \times g$ for $1 \mathrm{hr}$. The supernate was then fractionated with solid ammonium sulfate as described for adult human liver [12].

Double immunodiffusion was performed on 2.5- by $7.5-\mathrm{cm}$ glass slides containing $3 \mathrm{ml} 1 \%$ agarose in $1 \%$ saline. The antigen and antibody wells were $2 \mathrm{~mm}$ in diameter and $8 \mathrm{~mm}$ apart. Extracts of fetal and adult human liver were allowed to diffuse against the rabbit antihuman cystathionase serum for $24 \mathrm{hr}$ at $4^{\circ}$ or room temperature.

Immune precipitin bands were stained for cystathionase activity using a specific enzymatic stain based on the work of Feldberg and Datta [2]. After thorough washing in physiological saline and drying at room temperature, each slide was placed in an incubation mixture containing $100 \mu$ moles L-cystathionine, 500 $\mu$ moles potassium phosphate buffer ( $\mathrm{pH} 8.0$ ), $5 \mathrm{mg}$ nitro blue tetrazolium, and $5 \mu \mathrm{g}$ phenazine methosulfate, in a total volume of $5 \mathrm{ml}$. The reaction was allowed to proceed in the dark at $37^{\circ}$ for $20 \mathrm{~min}$, after which the slide was transferred to $2 \%$ acetic acid.

For absorption of antiserum, $25 \mathrm{mg}$ protein of either fetal or adult liver extracts were mixed with $1 \mathrm{ml}$ antiserum. The mixtures were allowed to stand for 1 $\mathrm{hr}$ at room temperature and then placed at $4^{\circ}$ for 3 days. Supernatant solutions for use in the immunodiffusion were removed after centrifugation at $12,100 \times g$ for $20 \mathrm{~min}$.

Immunotitration of human liver cystathionase preparations with rabbit antihuman cystathionase serum was carried out in a final volume of $350 \mu$ l containing as antigen either human adult liver extract (1.6 mg protein) or a mixture of adult (1.6 $\mathrm{mg}$ protein) and fetal liver extract ( $4.8 \mathrm{mg}$ protein), together with varying quantities of control or immune serum and saline. The mixture was kept at room temperature for $1 \mathrm{hr}$ and at $4^{\circ}$ overnight. Precipitates were removed by centrifugation at $2,500 \times g$ for $1 \mathrm{hr}$, and the supernates were assayed for cystathionase activity.

\section{Results and Discussion}

As reported earlier [11], crude extracts of human fetal liver had no measurable cystathionase activity. After ammonium sulfate fractionation, the fetal liver fraction obtained at $45-65 \%$ ammonium sulfate saturation showed a trace of cystathionase activity, $0.3 \mathrm{mU} / \mathrm{mg}$ protein, that is, apparently $3 \%$ of the value for the corresponding fraction of adult liver. However, this figure, because of the high tissue blank in the assay of fetal liver, is below the level which can be measured reliably. The fractions obtained at $0-30 \%$ and above $65 \%$ saturation had no cystathionase activity. Thus, an inhibitor separable by ammonium sulfate fractionation was not responsible for the lack of activity in the crude extract.

On double immunodiffusion of the crude extracts, a single thick precipitin band formed between the antiserum and the adult human liver preparation; a precipitin band uniting with this band did not form with the fetal preparation. After concentration of the crude fetal liver extract approximately three-fold, a precipitin band still could not be discerned (Fig. $1 A$ ), even after utilization of the specific enzyme-staining procedure (Fig. $1 B$ ). However, faint curling of the adult band in the direction of the wells containing the fetal extract can be seen in both figures, giving evidence of the presence of traces of cystathionase activity in fetal liver. Upon longer standing, both the adult and fetal liver extracts yielded one or two more very faint precipitin bands located nearer the antiserum well, not visible in the photograph. These faint bands, which could be removed by absorption of the antiserum with lyophilized human plasma, $60 \mathrm{mg} / \mathrm{ml}$, did not demonstrate cystathionase activity.

Absorption experiments demonstrated that the antibody to adult human cystathionase was precipitated when mixed with crude extract from adult liver. Thus, after absorption with lyophilized crude extract of adult liver, the antiserum no longer formed any precipitin bands upon immunodiffusion with adult liver. However, after absorption with the lyophilized crude extract of fetal liver, immunodiffusion of the antiserum with adult liver extract still demonstrated the formation of the thick precipitin band (Fig. 1C), which showed cystathionase activity after enzyme staining. The fainter bands normally developed upon longer standing failed to appear. Similar results were obtained when the antiserum to adult liver was absorbed with the ammonium sulfate fractions of fetal liver described above.

The specificity of the antiserum for cystathionase 
was confirmed by immunotitration: increasing quantities of antiserum were mixed with a constant amount of an adult liver preparation obtained by ammonium sulfate fractionation at $45-65 \%$ saturation. Increasing amounts of antiserum progressively removed the cystathionase activity, whereas nonimmune serum obtained from the same rabbit before immunization did not (Fig. 2).

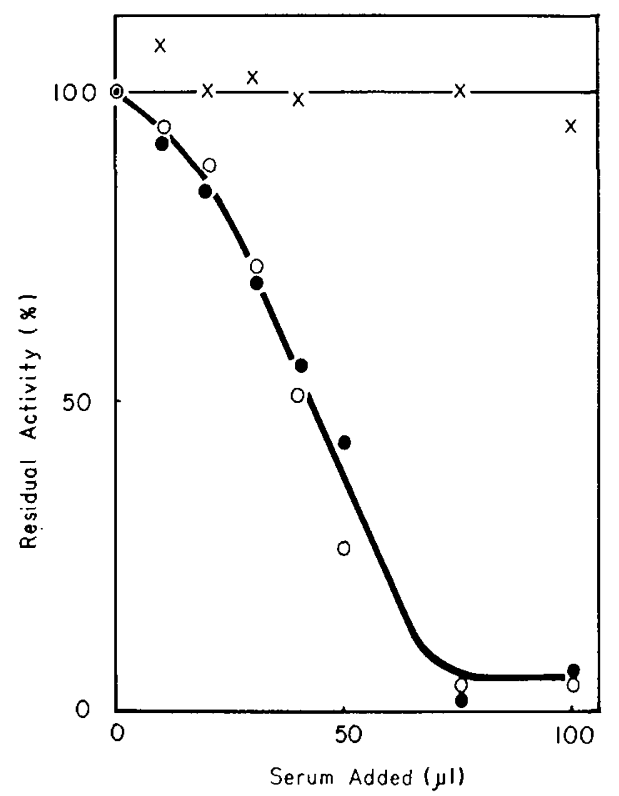

Fig. 2. Immunotitration of human liver cystathionase extracts with rabbit antihuman-cystathionase serum. The titrations depicted are control serum and adult liver extract $(X)$, immuneserum and adult liver extract $(O)$, immune-serum and a mixture of adult and fetal liver extracts $(\bullet)$.

Immunotitration provided an additional means by which proteins immunologically similar to cystathionase could be detected. With a mixture of the adult and fetal liver extracts, in which the amount of fetal liver extract was equivalent to three times the total protein in the adult liver extract, fetal liver did not decrease appreciably the reduction of adult liver cystathionase by a given quantity of antibody, thus confirming the virtual absence of a crossreacting protein in the fetal liver (Fig. 2). The absence of any appreciable alteration in activity upon mixing the enzymatically active extract of human adult liver with the virtually inactive extract of human fetal liver gives further evidence of the absence of inhibitors in the fetal liver or of activators in the adult liver.

The results demonstrate that the liver of the human fetus is not competent to synthesize more than trace amounts of cystathionase, nor does it synthesize an inactive precursor enzyme protein which can be detected immunologically.

Frimpter first established deficiency of cystathionase as the etiology of primary cystathioninuria [3]. Although it is not clear that primary cystathioninuria represents a distinct disease $[9,10]$, it would be of interest to learn whether it represents a persistence of the fetal condition into postnatal life or whether in this condition the altered gene results in the formation of a catalytically inactive but immunologically intact protein [14].

\section{Summary}

Immunochemical methods have been used to demonstrate that the human fetus does not synthesize more than trace amounts of cystathionase, nor does it synthesize a precursor enzyme protein immunochemically related to the adult enzyme.

\section{References and Notes}

1. Feigelson, M.: Estrogenic regulation of hepatic histidase during postnatal development and adulthood. J. Biol. Chem., 2f3: 5089 (1968).

2. Feldberg, R. S., and DatTa, P.: Threonine deaminase: a novel activity stain on polyacrylamide gels. Science, 170: 1414 (1971).

3. Frimpter, G. W.: Cystathioninuria: nature of the defect. Scicnce, 149: 1095 (1965).

4. Gaull, G. E., Rassin, D. K., and Sturman, J. A.: Enzymatic and metabolic studies of homocystinuria: effects of pyridoxine. Neuropädiatrie, 1: 199 (1969).

5. Greengard, O., AND Dewey, H. K.: Initiation by glucagon of the premature development of tyrosine aminotransferase, serine dehydratase, and glucose 6-phosphate in fetal rat liver. J. Biol. Chem., 2ł2: 2986 (1967).

6. Kretchmer, H.: Enzymatic patterns during development: an approach to a biochemical definition of immaturity. Pediatrics, 23: 606 (1959).

7. Meura, S., and Nakagawa, H.: Studies on the molecular basis of development of serine dehydratase in rat liver. $J$. Biochem., 68: 543 (1970).

8. Nemeth, A. M.: Mechanisms controlling changes in tryptophan peroxidase activity in developing mammalian liver. J. Biol. Chem., 234: 2921 (1959).

9. Perry, T. L., Hardwick, D. F., Hansen, S., Love, D., ani) IsRaELS, S.: Cystathioninuria in two healthy siblings. New Engl. J. Med., 278: 590 (1968).

10. Scotr, R. C., Dassell, S. W., Crark, S. H., Chiang-Teng, C., AND SwedberG, K. R.: Cystathioninemia: a benign genetic condition. J. Pediat., 76: 57 (1970).

11. Sturman, J. A., Gaul.., G. E., and Raiha, N. C. R.: Absence of cystathionase in human fetal liver: is cystine essential? Science, 169: $74(1970)$.

12. Tallan, H. H., Pascal, T. A., Schneidman, K., Gillam, B. M., AND GaUlL, G. E.: Homolanthionine synthesis by human liver cystathionase. Biochem. Biophys. Res. Commun., 43: 303 (1971). 
13. Whintraub, M., and Raymond, S.: Antiserums prepared with acrylamide gel used as adjuvant. Science, $142: 1677$ (1963).

14. Liver approximately 15 years old and stored at $-20^{\circ}$, from the first patient reported to have primary cystathioninuria (Harris, H., Penrose, L. D., and Thomas, D. H. H.: Ann. Hum. Genet., 23: 442 (1959)) was assayed for several liver enzymes. The values are expressed as percentages of those in normal human liver: cystathionine synthase, $10 \%$; $\mathrm{N}^{5}$-methyltctrahydrofolate-homocysteine-methyltransferase, $4 \%$; betainehomocysteine-methyltuansferase, 5\%; serine transhydroxymethylase, $0 \%$; and cystathionase, $0 \%$. Agar immunodiffusion studies performed with a concentrated homogenate from this liver $(98 \mathrm{mg}$ protein $/ \mathrm{ml}$ ) or a fraction obtained by ammonium sulfate fractionation at $45-65 \%$ saturation $(110 \mathrm{mg}$ protein $/ \mathrm{ml}$ ) and antiserum to human liver cystathionase failed to show a precipitin band which joined the band present in the normal human liver. However, when the homogenates from the cystathioninuric liver or the ammonium sulfate fraction were analyzed on immunoelectrophoresis using as antiserum, antibodies to human liver proteins developed in the donkey and absorbed with human plasma proteins, only approximately one-third of the precipitin bands present in a normal fresh human liver were found. Since this liver showed low cnzyme values and loss of some antigenic activity, caution must be applied to the speculation that the cystathioninuria observed in this patient was because of the absence of the cystathionase rather than because of altered but immunochemically intact protein. These equivocal results are included because of the unique and raxe material available.

15. Corning Ten Broeck, Corning Glass Works, Corning, N.Y.

16. Fetal tissues were obtained during a previous collaboration of Dr. G. E. Gaull with Dr. N. C. R. Raiha at the University of Helsinki.

17. We are inclebted to Dr. J. Sturman at the Institute for Basic Research, New York, N. Y., for locating the cystathioninuric liver and performing enzyme assays; to Dr. D. Cusworth, University College Hospital, London, England, for making this liver available; and to Dr. S. P. Halbert, University of Miami, Miami, Fla., for providing the donkey antihuman liver serum.

18. Supported by the Department of Mental Hygiene of New York State and the Lalor Foundation.

19. Requests for reprints should be addressed to: Theresa A. PASCAL, Institute for Research, 1050 Forest Hill Road, Staten Island, N. Y. 10314 (USA).

20. Accepted for publication May 12, 1972. 